\title{
On estimating the risk that shareholders bear during hostile merger activity
}

\author{
D.J. Bradfield* and D.C. Bowie \\ Department of Statistical Sciences, University of Cape Town, Rondebosch 7700, Republic of South Africa
}

Received 6 May 1991, accepted 23 August 1991

\begin{abstract}
In this article a model is proposed for measuring the risk that shareholders bear during hostile merger activities. An empirical study on the failed Minorco-Consolidated Goldfields merger attempt reveals several insights on the additional risk borme by Minorco and Consolidated Goldfields shareholders. Risk statistics computed using the proposed model reveal that shareholders of both companies were exposed to additional risk as a consequence of the hostility of the merger activities. The evidence shows that the proportion of risk attributable to the hostilities increased by a factor of approximately five for both bidding and defending companies.
\end{abstract}

In hierdie artikel word 'n model voorgestel wat die aandeelhouers se risiko gedurende vyandige samesmelting van maatskappye, kan meet. 'n Empiriese studie na die mislukte Minorco-Consolidated Goldfields-samesmelting gee verskeie insigte in die addisionele risiko wat deur die aandeelhouers gedra is. Risiko-statistieke wat met behulp van die voorgestelde model bereken is, dui daarop dat die aandeelhouers van albei maatskappye wel addisionele risiko ondervind het as gevolg van die vyandigheid van die samesmeltingsaktiwiteite. Daar word aangedui dat die deel van risiko wat aan die vyandighede toegeskryf kan word, met ' $n$ faktor van ongeveer vyf vermenigvuldig het vir albei maatskappye.

*Author to whom correspondence should be addressed.

\section{Introduction}

Merger activity has heightened in recent years leading to an increased demand for financial empirical research in this area. Hogarty (1970) was one of the first to make a significant contribution in this area by measuring the value of a merger to the acquiring firm. Halpern (1973) extended the literature by introducing the idea of measuring buyer and seller premiums in mergers directly by using the residual, or abnormal returns technique proposed by Fama, Fisher, Jensen and Roll (1969). Further results of studies by Ellert $(1975,1976)$ on the NYSE are supportive of the earlier findings of Halpern (1973) and Mandelker (1974), indicating that while acquired firms do gain significantly, the acquiring firms do not. On the JSE Affleck-Graves et. al. (1988) find similar evidence. Dodd (1980) used daily returns (rather than the monthly returns used in previous studies) to emphasize the importance of individual days in empirical work on mergers. He too showed that the target firm (as distinct from the term 'acquired' firm, which implies that the merger was successful) gained significantly at the news of the merger while the bidding firm lost. He also showed that gains made by the target firm's shareholders were maintained if the target firm called off the merger, but that they fell if the bidding firm cancelled it.

The focus of this article is on hostile merger activities. Usually during merger activities one of the merging companies can be identified as the 'bidding' company and the other the 'target' company. Typically during hostile merger activities the target company attempts to fend off takeover attempts by the bidding company. These takeover and defensive strategies of the respective bidding and target firms usually involve substantial sums of capital and may sometimes occur at the expense of the shareholders. Brealey and Myers (1981) argue that takeover battles are undoubtedly exciting for the individuals involved but are not always conducted with the best interest of the shareholders in mind.

Although much attention in the literature has focused on estimating the gain/loss to shareholders of the target and bidding firm of the post merger company, little attention has focused on the risk aspect. Thompson (1983) and Barr and Van den Honert (1988) have considered the change in the systematic risk of the post merger firm, but little has been said concerning the risk that shareholders bear during hostile merger activities. It is conceivable that investor's perceptions on the pricing of the companies involved in hostile merger activities are likely to change in line with the takeover/defence strategies employed causing additional share price volatility. Consequently shareholders of either or both of the comparies involved may be exposed to additional risk.

In this article a technique is proposed for measuring the risk that shareholders of both the bidding firm and the target firm bear during hostile merger activities. In the first section of this article the model is proposed. In the second, data relating to the classic Minorco/Consolidated Gold Fields failed merger attempt will be used to demonstrate how the model can be implemented. Finally some conclusions are offered.

\section{The model}

The model proposed below is designed to estimate the component of risk attributable to the hostile merger activities. This model is proposed within the well-known two-parameter (mean-variance) framework of Markowitz (1952, 1959), where the variance of a securities return is interpreted as the total risk of the security.

The dependent and independent variables of the model can easily be rearranged to estimate the additional risk from the viewpoint of the shareholders of either the bidding or target firms. The model shown below is formulated from the viewpoint of the target company, i.e. the risk associated with resisting attempts to be taken over by the bidding firm.

The model relates the return on the target company to the return on the market index plus the return on the bidding company. This model has the form of an extended Market 
Model. In order to obtain expressions for the risk components of the target firm (shown in the development that follows), the vector of the market index returns and the returns of the bidding company (i.e. the independent variables) are orthogonalized. This amounts to removing the effects of the market index from the returns of the bidding company. This orthogonalizing procedure is simply achieved by regressing the retums of the bidding firm on the returns of the market index, and using the resultant residuals to represent the returns on the bidding firm in the model.

Hence the model can be written as:

$R_{t}^{T}=\alpha_{t}+\beta_{T}^{M} R_{t}^{M}+\beta_{T}^{B-M} R_{t}^{B}-M+e_{t}$

where:

$R_{t}^{T}$ is the retum on the target firm at time t;

$R_{L}^{M}$ is the retum on the market index at time $t$;

$R_{t}^{B-M}$ is the residual return on the bidding firm at time $t$, obtained by regressing the returns of the bidding firm on the market index returns;

and $a_{T}, \beta_{T}^{M}$ and $\beta_{T}^{B-M}$ are coefficients unique to the target firm.

The following assumptions regarding the $\mathrm{e}_{\mathrm{l}}$ are made:

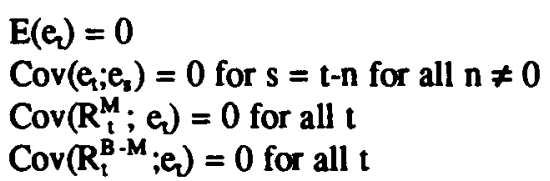

The components for the total risk of the target company can be obtained by considering the expression for the variance of the returns of the target company using model (1).

$$
\begin{aligned}
& \operatorname{Var}\left(R_{t}^{T}\right)=\operatorname{Var}\left(\alpha_{\mathrm{T}}+\beta_{T}^{M} R_{t}^{M}+\beta_{T}^{B-M} R_{T}^{B-M}+e_{1}\right) \\
& =\operatorname{Var}\left(\alpha_{T}\right)+\beta_{T}^{M^{2}} \operatorname{Var}\left(R_{t}^{M}\right)+\beta_{T}^{B-M^{2}} \operatorname{Var}\left(R_{t}^{B}-M\right) \\
& +2 \beta_{T}^{M} \beta_{T}^{B-M} \operatorname{cov}\left(R_{t}^{M}, R_{t}^{B-M}\right)+\operatorname{Var}\left(G_{t}\right)
\end{aligned}
$$

Since $\alpha_{T}$ is constant $\operatorname{Var}\left(\alpha_{T}\right)=0$ and, by construction $\operatorname{Cov}\left(R_{t}^{M} ; R_{t}^{B-M}\right)=0$, the above expression simplifies to:

$\operatorname{Var}\left(R_{\mathrm{t}}^{\mathrm{T}}\right)=\beta_{\mathrm{T}}^{M^{2}} \operatorname{Var}\left(\mathbf{R}_{\mathrm{t}}^{M}\right)+\beta_{T}^{B}-M^{2} \operatorname{Var}\left(R_{\mathrm{t}}^{\mathrm{B}-M}\right)+\operatorname{Var}\left(\mathrm{e}_{\mathrm{t}}\right)$

Thus the above expression can be interpreted as:

Total risk of the target company $=$ market risk + risk attributable to resisting the merger + unique risk

The model can also be formulated from the viewpoint of the 'bidding' firm. In this instance the model can be written as:

$R_{t}^{B}=\alpha_{B}+\beta_{B}^{M} R_{t}^{M}+\beta_{B}^{T-M} R_{t}^{T-M}+e_{t}$

where:

$R_{t}^{\mathbb{B}}$ is the retum on the bidding firm at time $t$;

$R_{i}^{T-} M_{i s}$ the residual return on the target firm at time $t$, obtained by regressing the returns of the target firm on the returns of the market index; and

$\alpha_{B}, \beta_{B}^{M}$ and $\beta_{B}^{T-M}$ are coefficients unique to the bidding firm.

Similarly an expression for the total risk of the bidding firm, similar to equation (2) can be derived, i.e.
$\operatorname{Var}\left(R_{t}^{B}\right)=\beta_{B}^{M^{2}} \operatorname{Var}\left(R_{t}^{M}\right)+\beta_{B}^{T-M^{2}} \operatorname{Var}\left(R_{t}^{T-M}\right)+\operatorname{Var}\left(e_{\mathfrak{t}}\right)$

which can be interpreted as:

Total risk of the bidding company $=$ market risk + risk attributable to attempting a takeover + unique risk

In the next section the model will be implemented on the classic Minorco-Consgold hostile merger activities to demonstrate how the model can be used to estimate the relevant components of risk.

\section{An empirical demonstration}

The Minorco-Consgold merger attempt during 1987-1989 captured the interest of the investment media and also provides an opportunity to demonstrate the use of the proposed model.

Minorco, a Luxembourg-based investment company, made a bid for Consolidated Gold Fields (Consgold), a natural resource company in the United Kingdom, on 21 September 1988 which was immediately contested. The battle for control lasted over 8 months and, because of its high profile, captured substantial interest and consequently was well-documented in the finance media.

The data used in this demonstration comprises the daily returns of Minorco and Consgold from 30 October 1987 to 7 August $1989^{1}$ as quoted on the Johannesburg Stock Exchange (JSE) as well as the JSE Actuaries Mining Financial Index. The return on the market was proxied by the retum on the JSE Actuaries Mining Financial Index in which both Minorco and Consgold were listed.

Of particular relevance for the implementation of the model is the date of the first and last evidence relating to the hostile merger activity. Hence the data was partitioned into three sections, namely:

Prior to merger attempt: 30 October $1987^{2}-20$ September 1988

During merger attempt: 21 September 1988-17 May 1989

After merger attempt: 18 May 1989-7 September $1989^{3}$

In Table 1 the resulting risk statistics are shown from the viewpoint of the target firm's shareholders, Consgold, using

Table 1 Risk borne by Consgold Shareholders

\begin{tabular}{lccccc}
\hline & $\begin{array}{c}\text { Number of } \\
\text { Obs. } \\
\text { (days) }\end{array}$ & Befriod & $\begin{array}{c}\text { Defending } \\
\text { risk } \\
(\%)\end{array}$ & $\begin{array}{c}\text { Market }^{b} \\
\text { risk } \\
(\%)\end{array}$ & $\begin{array}{c}\text { Unique }^{c} \\
\text { risk } \\
(\%)\end{array}$ \\
\hline Prior & 237 & -0.21 & 5.3 & 7.6 & 87.1 \\
During & 161 & -0.51 & 22.9 & 1.3 & 75.8 \\
After & 79 & 0.13 & 1.4 & 4.1 & 94.5 \\
\hline
\end{tabular}

The above statistics are obtained from the regression:

$R_{i}^{T}=\alpha_{T}+\beta_{T}^{M} R_{t}^{M}+\beta_{T}^{B \cdot M} R_{t}^{B \cdot M}+C_{T}$

a. Defending risk is calculated as $\beta{ }_{T}^{B \cdot M^{2}} \operatorname{Var}\left(R_{t}^{B} \cdot M\right)$ and is expressed as 2 percentage of Total Risk.

b. Market risk is calculated as $\beta_{T}^{M^{2}} \operatorname{Var}\left(R_{1}^{M}\right)$ and is expressed as a percentage of Total Risk.

c. Unique risk is calculated as $\operatorname{Var}\left(e_{1}\right)$ and is expressed as a percentage of Total Risk. 
quired and acquiring companies. S.Afr. J. Bus. Manage., Vol. 19: 147-153.

Barr, G.D.I. \& Van den Honert, R.C. 1988. Diversifying mergers and risk: A comment. J. Econ. Studies, Vol. 15, No. 5: 53-64.

Brealey, R. \& Myers, S. 1981. Principles of corporale finance. New York: McGraw-Hill.

Dodd, P. 1980. Merger proposals, management discretion and stockholder wealth. J. Econ. Studies, Vol. 8: 105-137.

Ellert. J.C. 1975. Antitrust enforcement and the behaviour of stock prices. Doctoral dissertation. Chicago: Graduate School of Business, University of Chicago.

Ellert. J.C. 1976. Mergers, antitrust law enforcement, and stockholders returns. J. Fin., May, 715-732.

Fama, E.F., Fisher, L., Jensen, M. \& Roll, R. 1969. The adjust- ment of stock prices to new information. International Econ. Rev., Vol. 10: 11-21.

Halpem, PJ. 1973. Empirical estimates of the amount and distribution of gains to companies in mergers. J. Bus., Vol. 46: 554-575.

Hogarty, T.F. 1970. The profitability of corporate mergers. J. Bus., Vol. 43: 317-327.

Mandelker, G. 1974. Risk and return: The case of merging firms. J. Fin. Econ., Vol. 6: 366-383.

Markowitz, U.M. 1952. Portfolio selection. J. Fin., Vol. 7: 77-91.

Markowitz, H.M. 1959. Portfolio selection: Efficient diversification of investments. New York: Wiley \& Sons, p77-91

Thompson, R.S. 1983. Diversifying mergers and risks: Some empirical tests. J. Econ., Vol. 10, No. 9: 12-21. 